\title{
PJIEE
}

Premise: Journal of English Education and Applied Linguistics

https://fkip.ummetro.ac.id/journal/index.php/english

Pranoto and Suprayogi

\section{A NEED ANALYSIS OF ESP FOR PHYSICAL EDUCATION STUDENTS IN INDONESIA}

\author{
BUDI EKO PRANOTO \\ UNIVERSITAS TEKNOKRAT INDONESIA \\ Budiekopranoto@teknokrat.ac.id \\ SUPRAYOGI \\ UNIVERSITAS TEKNOKRAT INDONESIA
}

Suprayogi@teknokrat.ac.id

\begin{abstract}
:
This research aims at constructing the ideal English material for Physical Education students of universities in Lampung. Currently, students at university are taught about general English and it stimulates the writers to conduct a research to reveal their need of ESP as the answer of the current issues. This research is conducted in two universities, namely Universitas Teknokrat Indonesia and Universitas Lampung. The participants are 50 students, and 10 lecturers of Physical Education study program from both respective universities. The data are in the form of qualitative data which are taken from the interview and the questionnaire to students and lecturers which cover topics needed, and teaching method. The findings reveal the Physical Education students' need of ESP in varied range of topics. The highly desired topics are English for sport journalism, English for professional athlete/referee/coach. Furthermore, based on the perspective of lecturers, they believe that students' speaking, and writing must be well developed in order to compete in international level as professional athlete, coach, journalist, and etc. The result of analysis concludes the importance of ESP for Physical Education's students. Further research shall be conducted to test the effectiveness of the English topics constructed based on this current research.
\end{abstract}

Keywords: ESP, Need Analysis, Physical Education

\section{INTRODUCTION}

The demand for an innovative ESP for university students in Indonesia has increased in recent years since ESP provides a more advanced, specialized, and academic material, and matches study program taken by students, particularly at higher education setting where students are trained to perform on-the-job (Kusni, 2013). Numerous experts have exposed their ideas about the key concept of ESP in the English language teaching context. Kusni (2013,p.37) elaborated 
that the classification of ESP can be seen in Mackay and Palmer (1981), Carter (1983), and McDonough (1984). In this matter, Hutchinson and Waters (1987) provide a comprehensive diagram of ESP which shows that ESP is a branch of ELT. Moreover, ESP may have been subcategorized into many subfields of specially prepared English lessons, such as in Science and Technology, Business and Economics, and Social Sciences. Each of English lessons specially design for that fields can be included into two main branches namely English for Academic Purposes (EAP) or English for Occupational Purposes (EOP). ESP is programmed on the basis of a careful and systematic needs analysis that aims to reveal the learners' needs in learning English. The choice of goals or objectives, materials, contents, and methods of teaching are also based on the target learners ${ }^{e e}$ needs. So, the main focus of teaching ESP is to the process of determining English skills and components related to the students' needs and their field of study (Kusni, 2013).

Regarded as a data collection process instrument, the use of Need Analysis (NA) is inevitable to obtain better paradigm on language skills, English in this context, should be prepared and distributed (Parnawati and Ulinuha, 2019). Furthermore, Akyel \& Ozek (2010) explained that Need Analysis is a solid and effective instrument that assists teachers in clarifying the essential needs of students. This instrument opens possibilities for teachers to adjust the curriculum advancement that addresses the learners' interests. Therefore, Needs Analysis is a vital treasure for lecturers of English for Specific Purposes (ESP) to reveal students' pivotal requirements or necessities and determine the English skills they need to develop in order to succeed in the future.

The debate on the focus of needs analysis has aroused among experts; Benesch (2001,p.72) argues that needs analysis is strongly related to the goal of learning, while Hutchinson and Waters (1991) consider learning needs as the needs of learner required during the learning process. Empirically, other researchers mentioned that the success in the teaching and learning activities in ESP depends on the implementation of Needs Analysis conducted prior to the program. Needs analysis is the key to creating a suitable learning system and process to achieve the learning goal (Kusni, 2013; Poedjiastutie and Oliver, 2017; Rokhyati, 2013). Needs analysis identifies the learners' characteristics and skills in general; include weaknesses and strengths that are based on the academic context specifically. It is in accordance with the objective of ESP, that English skill is better if suited accurately with the learner's core capabilities. 
In the Indonesia context, many researchers have conducted research on Need analysis of ESP for numerous study programs; as Parnawati \& Ulinuha (2019) on Needs of English at higher education level, Susandi \& Krishnawati (2016) on Nursing students, Diana and Mansur (2018) on ICT students. These studies aimed at constructing the ideal goal, topic, and learning strategies in each respective study program in order to make the student possess the English skills needed for their future. Yet, there is no research that discusses ESP for the Physical Education study program both on the level of need analysis and syllabus design.

In the present time, all of the students of Physical Education study program are learning general English which hasn't touched the core capabilities of the student for their goal in the future. According to Kusni ( 2013), "at universities or higher education, the students should have been offered ESP not EGP anymore. Higher education authorities should claim that EGP, as the long-existing practice of English language teaching in Indonesia universities, should be replaced by ESP." Therefore, this current research presents to enrich to the bulk of research on ESP Needs analysis of Physical Education students.

Based on the conditions explained above, the researchers believed that is crucial to search about how Physical Education students perceive their English abilities and to reveal the topics needed in ESP for Physical Education students. The objective of research attempts to help ESP teachers in Indonesia to identify the fine methods and English material for teaching that are well-suited to Physical Education students. The results of Need Analysis in this research are going to be employed as the basis of the construction of the syllabus.

\section{The Basic Concepts and Characteristics of English for Specific Purposes (ESP)}

It is necessarily vital to mark the difference drawn between English for Specific Purposes (ESP) and English Language Teaching (ELT), both EFL and ESL. Most people assume that ESP is merely a language-centered approaches for specialized language learners to equip them with specific and professional English language skills through context-based material. The activity of learning English in ESP class is not much different than those of general English, but ESP class is characterized by its various contents of learning. Moreover, ESP can be the stepping stone to learning any kind of English level. In this case, "ESP should be seen as a method/approach not as a product”. Paltridge \& Starfield (2012) illustrates that ESP is a learnercentered approach to learning English. 
Not until the late 1960s, the role of ESP was not prominently crucial. Basturkmen (2010) stated that ESP was particularly associated with the notion of a specifically constructed English subject to address the need of communication int the field of science and technology. Therefore, it is crucial to create accurate materials to achieve a goal or learning. This bases the application of need analysis to gain the learners' perspective of English learning and language skills. A need analysis of ESP is required to draw the condition and reality of English skills that are relevant to their core capabilities. As the result, teachers of ESP classes should provide unique and exclusive English skills to fulfill students' needs to succeed in a future career.

Dudley-Evans and St John (1998), Hyland (2006), and Harding (2006) in Kusni (2013,p.37) stated that the terminology "specific" in English for Specific Purposes refers to the specialization of aim and target. Dudley-Evans and St John (1998) in Kusni (2013) propose the classification of ESP based on discipline or professional field as shown in Diagram 1 below

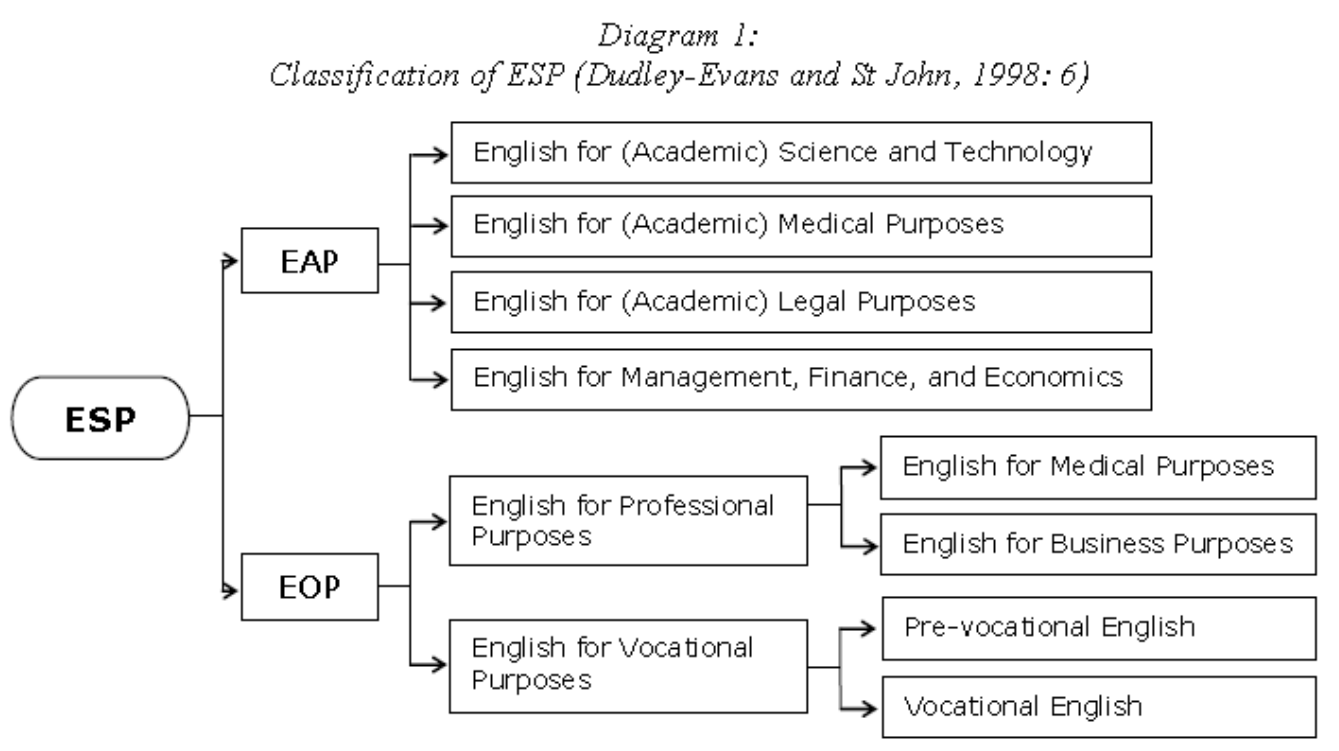

Diagram 1 (cited from Kusni, 2013) above displays the branches of ESP namely English for Academic Purposes (EAP), and English for Occupational Purposes (EOP). This distinction is crucial since they will level exclusivity designed in the ESP. EAP refers to English as a course for academic purposes which develops English language skill of the learner for the academic purposes. On the other hand, EOP refers to English for occupation or professional purposes (Kusni, 2013). In this respect, English for Sport purposes is included in EOP since its purpose it to enhance the learners' English skill for professional purposes. 


\section{A Need Analysis}

Needs analysis has developed and regarded as one of the main instruments in language learning process, either general English or ESP. The overview of needs analysis in language teaching has depicted its history, theoretical foundation, and approaches (Lee, 2016). The importance of learners' perspective in developing the principle of curriculum of ESP has also been noted by many experts. They argue that the learners' perspective mostly covers the area at which they will exercise their English skill in the future. Moreover, research on the needs of language learners should be performed by assessing their needs through survey and interview. The survey and interview are given to student and faculty members to obtain backgrounds, and goal targeted. The more the students needs are obvious, the more the aims are articulated. Thus, the ESP class becomes successful (Lee, 2016,p.97)." Therefore, it is concluded that needs analysis as one of the instruments in material development that consists of needs analysis, formulating goals, and organizing the course content.

Currently, Needs Analysis is a pivotal and must-used instrument (as guidance and evaluation of the course) in language teaching. Needs analysis can help teacher traces the information of the skills mastered by the students and skills they want to upgrade and improve. A need analysis goes along several procedures; data collection on the perspective of students' desires learners' needs and hopes, beliefs and viewpoints (Lee, 2016). Therefore, the detail information such as materials, method, and class environment are comprehensively acquired for the sake of learning goals and target (Boroujeni \& Fard, 2013).

To answer the problem elaborated above, this research aimed at addressing these following research questions:

1. How do Physical Education students perceive their English abilities?

2. What are the topics needed in ESP for Physical Education students?

\section{METHOD}

\section{Design}

In a Research and Development (R \& D) based research, Need Analysis is considered as the first move. In regard to this, this research focused on the Need Analysis of ESP for Physical Education students, therefore a triangulation research design was utilized combining both quantitative and qualitative. Quantitative method was used to gain information from all 
respondents (physical education students); meanwhile the qualitative method (interview) was used to gain more insight from the lecturers regarding their projection on the use of English for sports in the future.

\section{Participants}

The demographic of the respondents was as follows; 25 students 5 lecturers of Universitas Teknokrat Indonesia, and 25 students and 5 lecturers of Universitas Lampung, voluntarily participated in this research. All of the students were Physical Education majors who had passed English Subject level 1 when this research was conducted and all of lecturers are currently teaching in the department. Their English proficiency level range was between elementary to advanced ones.

\section{Instruments}

There are two categories of data: quantitative, and qualitative data. The quantitative data were gathered from questionnaire responded by designated participants. The questionnaire was distributed online. The qualitative data were gathered through interview sessions held with some of the respondents of research.

\section{Data Collecting Technique}

The data of this research were collected using an online survey, and interviews about individual entitled to the topic discussed. The survey is objected to reveal the attitude, behavior, beliefs, and arguments of the respondents about their needs of English skills in higher education setting (Cohen, 2015). In this research, a questionnaire was used as the primary tool to obtain the quantitative data. The questionnaire served to investigate the skills and attitude of participants toward ESP. The data gathered from the questionnaire were directly analyzed quantitatively using basic statistical procedures. To collect the data, the researcher distributed the questionnaire to respondents using Google.doc. The qualitative data were gathered from interviews conducted to several respondents. The interview is carried out to confirmed the quantitative data.

\section{Data Analysis Technique}

The data analysis is started by downloading the answered questionnaires, and calculating the data using simple statistical procedure. In order to obtain a deeper and detailed 
of the findings, the researcher conducted interviews to several respondents. This oral data is used to support and confirmed the finding and result of the analysis.

\section{RESULT AND DISCUSSION}

\section{Result}

The following section outlines the results from the data collection process that is classified into two sections. The first section presents the participants' personal details and English proficiency. The result leads to identify the level of confidence for each skill since the questionnaire was served as a self-assessment instrument. The second part describes the data about the language need through the selection of topics/materials needed and wanted by Physical Education students and lecturers to be included in the ESP for physical education students (table 3 and 4).

\section{Students' Personal Information and Language Skills}

The students' personal information and language skills proficiency were identified using questionnaire containing specific question to address the issues discussed.

Table 1. Personal Information of the Respondents

\begin{tabular}{|c|c|c|c|c|}
\hline & & & Frequency & Percentage \\
\hline 1. & Gender & $\begin{array}{l}\text { Man } \\
\text { Woman }\end{array}$ & $\begin{array}{l}35 \\
15\end{array}$ & $\begin{array}{l}70 \% \\
30 \%\end{array}$ \\
\hline 2. & Age & $\begin{array}{l}19-21 \\
22-24 \\
25-28\end{array}$ & $\begin{array}{c}42 \\
8 \\
-\end{array}$ & $\begin{array}{c}84 \% \\
16 \% \\
- \\
\end{array}$ \\
\hline 3. & $\begin{array}{l}\text { Has passed English } \\
\text { Subject }\end{array}$ & $\begin{array}{l}\text { Yes } \\
\text { No }\end{array}$ & $\begin{array}{l}38 \\
12\end{array}$ & $\begin{array}{l}76 \% \\
24 \%\end{array}$ \\
\hline 4. & $\begin{array}{l}\text { Make effort to improve } \\
\text { English skills }\end{array}$ & $\begin{array}{l}\text { Yes } \\
\text { No }\end{array}$ & $\begin{array}{l}30 \\
20\end{array}$ & $\begin{array}{l}60 \% \\
40 \%\end{array}$ \\
\hline 5. & $\begin{array}{l}\text { Frequency of practicing } \\
\text { English outside campus }\end{array}$ & $\begin{array}{l}\text { Not at all } \\
1-2 \text { hours } \\
4-5 \text { hours } \\
\text { More than } 5 \text { hours }\end{array}$ & $\begin{array}{c}14 \\
26 \\
8 \\
2\end{array}$ & $\begin{array}{c}28 \% \\
52 \% \\
16 \% \\
4 \%\end{array}$ \\
\hline
\end{tabular}

Table 1 above presents the personal information of the respondents (Universtias Teknokrat Indonesia \& Universitas Lampung). Most of them are male (70\%), ranging from 19 to 24 years old, but only $16 \%$ are $22-24$ years old; the rest $84 \%$ are under 22 years old. Almost all of them 
have passed English subject in their respective study program, however there are 12 respondents (24\%) who haven't passed the subject. In regard to their motivation in improving their skills in English, only $60 \%$ of the respondents make efforts to improve their English. The lack of motivation and effort is also seen by the small numbers of respondents, $4 \%$, who practice their English skill for more than 5 hour per week. It is surprisingly that there are $28 \%$ of the respondents who admit that they don't practice their English outside campus; at all. This personal information was then followed by the description of respondents' perception on their English proficiency level. The researcher divided the level into 4; very weak, weak, good, and very good. The distribution of respondents' response is in Table 2. below.

Table 2. Physical Education students' English proficiency level

\begin{tabular}{|l|c|c|c|c|}
\hline \multicolumn{1}{|c|}{ Competency } & $\begin{array}{c}\text { Very } \\
\text { weak }\end{array}$ & Weak & Good & Very good \\
\hline Speaking & $29 \%$ & $53 \%$ & $13 \%$ & $5 \%$ \\
\hline Listening & $48 \%$ & $42 \%$ & $10 \%$ & - \\
\hline Reading & $16 \%$ & $26 \%$ & $44 \%$ & $14 \%$ \\
\hline Writing & $15 \%$ & $20 \%$ & $47 \%$ & $18 \%$ \\
\hline Grammar & $28 \%$ & $52 \%$ & $20 \%$ & - \\
\hline Vocabulary & $30 \%$ & $56 \%$ & $14 \%$ & - \\
\hline Pronunciation & $40 \%$ & $48 \%$ & $12 \%$ & - \\
\hline
\end{tabular}

The data provided on Table 2 describes students' confidence in identifying their core competencies of English, those are speaking, listening, grammar, vocabularies, pronunciation, and writing. The percentage reveals that their English skills need to be improved. The first, for the speaking ability, more than half of the respondents (53\%) claimed that their speaking ability is weak and $29 \%$ of students claimed theirs is very weak. In the other hand, $13 \%$ of respondents stated that speaking ability is good, meanwhile only $5 \%$ students claimed to have a very good speaking ability. These findings are also confirmed by their response on vocabulary and pronunciation abilities, since speaking skill is crucially supported by these two competencies.

In the table above, the students dominantly mentioned that their vocabulary mastery is weak with the total of $86 \%$. The rest of respondents (14\%) considered their vocabulary mastery is good. Meanwhile, none of students check-listed "very good" section. The second influential skill to speaking, pronunciation, also was claimed to be the skill they are not confident with. $40 \%$ of student felt that their pronunciation clarity is very weak, and $48 \%$ of students saying it is weak. Based on the distribution of claims made by respondents, it can be observed that most 
respondent considered themselves to have weak speaking skill and also very weak. Thus, the findings support the assumption that respondents are less confident when speaking in English.

The second, students' listening ability is not significantly different from speaking ability. Table 2 above depicted that $48 \%$ of respondents stated that their listening proficiency is very weak. Then it is followed with $42 \%$ of respondents who believed that their listening proficiency is weak. Less then quarter (13\%) of respondents responded that their listening proficiency is good. It is surprising that none of students claiming that their listening proficiency is good like what was found in speaking skill. In average, most of the respondents stated their listening proficiency is weak the "good" level received the fewest percentage. Therefore, it is assumed that generally, students are not confident with their listening proficiency

The third, reading skill received contrast response from students. As found in other studies, respondents generally confident with their reading skill and it is also confirmed in this research. There are $44 \%$ of respondent who classified their reading skill is good and $14 \%$ as good. Though the number of respondents who considered that their reading skill is weak is quite high (26\%), the total "good" percentage still dominates the total responses (58\%). Among those numbers, $16 \%$ of respondents felt that their reading comprehension skill is very weak.

On top of all, most of the students classified their reading as good though there are a few numbers of students who categorized their reading comprehension skill as weak. But compared to two previous skill, reading skill topped them all. By this finding, it can be predicted that students are more confident with their reading comprehension skill than the ability on listening, and speaking writing, it can be assumed that students are more confident with their reading skill than their skill on listening, and speaking.

The fourth is students' perception on their writing skill. In this research, perception on writing skill is combined with grammar skill since these two skills are inevitable. Based on Table 2, most students (44\%) stated that their writing skill is good. Furthermore, there are 18\% of students who declared their writing skill as very good. In the other hand, $20 \%$ students said that they have weak skill of listening, and the rest (15\%) claimed that their writing skill is very weak. In regard to this, students' response on grammar skill doesn't support the findings on writing skill, because there are only $20 \%$ who perceived that their grammar skill is good. In fact, almost half of students (48\%) declared that their grammar accuracy is weak and followed with $28 \%$ of students who said "very weak". Overall, the findings show similarities to those on reading skill. Therefore, it can be inferred that respondents are also quite convinced with their 
writing skill compared to speaking and listening skill. Later, this finding is also supported by the topic preference on sport journalism. In collecting the topics needed to develop students in the future, the researcher also collected information about who/what-they-want-to-be in the future. It based on the reason that English skills taught must support their career progress in the long-term manner. The researcher found 5 main goals of Physical Education students as they graduate from the institution.

The table below shows the distribution of profession dreamed by students.

Table 3. Physical Students' goals

\begin{tabular}{|l|c|c|}
\hline \multicolumn{1}{|c|}{ Profession/ Occupation } & $\begin{array}{c}\text { Number of } \\
\text { students }\end{array}$ & Percentage \\
\hline Teacher & 16 & $32 \%$ \\
\hline Sport Journalist & 14 & $28 \%$ \\
\hline Professional Athlete & 9 & $18 \%$ \\
\hline Professional Referee & 8 & $16 \%$ \\
\hline Professional Coach & 3 & $6 \%$ \\
\hline
\end{tabular}

Table 3 above shows the distribution of kinds of occupations desired by respondents who are currently taking Physical Education major. Two occupations, teacher and sport journalist, received a high response from respondent. There are $32 \%$ of total respondent who want to be a teacher in the future, and $28 \%$ sport journalist. There rest of respondents select Professional athlete, referee, and coach in consecutive order. From both universities, most of the students pick teacher as the main occupation in the future. The findings in the table above are in accordance with the aim of the study program to prepare a teacher in the field of sport.

\section{The topics needed in ESP for Physical Education students}

Using questionnaire and interview method to participants, the researcher gathered information to be taken into account as part of ESP for Physical Education students. The topics, distributed in the questionnaire, were shorted based on the observation made at Universitas Teknokrat Indonesia, and Universitas Lampung. Generally, the students in both universities received general English with modification related to business environment activities. The observation concludes that Physical Education students in Lampung has received these topics, such as Greeting \& Introduction, Personal details, and etc. Therefore, the writer didn't include these topics as the option. Furthermore, lecturers from both universities were also interviewed on their desired topic which needed to be taken into account in ESP. Table 4 below shows the preference of students and lecturer (in percentage) on specific topics on sports and education. 
Table 4. Students' and lecturers' preferred topics

\begin{tabular}{|l|c|c|}
\hline \multicolumn{1}{|c|}{ Topics } & Student & Lecturer \\
\hline Teaching Instruction & $100 \%$ & $100 \%$ \\
\hline English for Sport Journalism & $90 \%$ & $90 \%$ \\
\hline How to communicate as Professional Athlete & $80 \%$ & $100 \%$ \\
\hline How to communicate as Professional Referee & $80 \%$ & $100 \%$ \\
\hline How to communicate as Professional Coach & $70 \%$ & $80 \%$ \\
\hline The Human Body and Physiology & $60 \%$ & $100 \%$ \\
\hline Body Movement and Exercise & $60 \%$ & $100 \%$ \\
\hline Categorization of Sports & $60 \%$ & $90 \%$ \\
\hline
\end{tabular}

These findings are in line with the findings on occupation dreamed by students. Being teacher receives a high degree of response from students. It is then followed by $100 \%$ response from respondent on the importance of "teaching instruction" topic. All lecturers also emphasize the importance of "teaching instruction" topic since most of graduate will become a teacher. Therefore, they need to master teaching instruction skills. The second that surprises the researcher is "English for Sport Journalism". Both students and lecturers respond it positively high with $90 \%$. Though it will be a tough topic due to the fact that not all students of both universities possess an advance level of English proficiency (see table 2), but it is believed as a breakthrough in ESP topic provided for Physical Education students. Moreover, this skill is important for their future as sport journalist. Topics on communication as professional athlete, referee, and coach receive a fair percentage from students yet the lecturers respond it differently.

\section{- $\quad$ Syllabus of ESP For Physical Education Students}

The writer adopts learners-centered approach as the basis in developing the innovative syllabus. This approach was also employed to collaborate with the core of an ESP module. Then, the design focuses on the specific needs of learners which required by Physical Education students during learning process. Besides, the assessment is also an important aspect to measure the learners' performances. This may be obtained through performance-based tests and feedback from lecturers. The assessment aims to give a more qualitative perspective on the effectiveness of the topics and teaching procedures once they are implemented.

\section{- Material Development for the ESP Syllabus}

Material development in teaching ESP is very essential; it shows the creativity and the awareness of the teacher towards the subject. Materials can be defined as anything or any source that can be used to assist the student in the process of language learning. In designing the 
material, the designer has to ensure that the material meets the needs of the learners. Paltridge $\&$ Starfield (2013) suggested three recommendations to consider in designing the materials:

1. Context based text and situation taken from the student' core competencies - both real or stimulated. Those will naturally open the access to language needed by students.

2. Exploit inherently unique materials that address students' specialty and major.

3. Make the task authentic as well as the tasks - bring the student to perform activities with the materials that they actually need to do in their work setting in the future.

In the case of physical students, the materials used for these students are materials integrated with the real-world situation, their working situation as teacher, sport journalist, professional athlete, referee, and coach. However, with the limited amount of time in each meeting, designing an appropriate material and syllabus for the proposed time frame are relatively complicated. The findings on this study revealed that it is necessary to improve the students' English proficiency (see Table 2). The first English proficiency that needs to be improved is the speaking skill. Students identified that their speaking skill is not good enough; mostly answered that their speaking ability is weak.

\section{Discussion}

In the case of students' English proficiency, reading comprehension and writing skill a dominant result among the seven skills assessed from the questionnaire. Though the positive response is not strongly dominant (less than 70\%), it still points that most respondents are convinced with their ability of writing and reading. This findings in accordance with the finding of Susandi and Khrisnawati (2016) which revealed the students in EFL setting tend to have higher reading skill than others. Furthermore, Choi, Moon, Paek, \& Kang (in Parnawati \& Ulinuha, 2019) stated that there is an inherent relation between reading comprehension skill and writing. Therefore, these two skills correspond each other. If student has a good confident with their reading, usually they also have a good confidence with their writing and vice versa. This finding also supports the claim made by Diana and Mansur (2018) who stated that students in EFL setting are motivated to learn writing skill more than other skills. Although writing is favored by students, they show less confidence on their grammar skill. It is interesting to reveal the motivation why the students are not confident with their grammar but are confident with their writing skill. In fact, writing and grammar skill are inherently related. Thus, it needs 
further research which aimed at elaborating this finding. The upcoming research should pay attention on students writing and grammar at the designated university.

The students' perception on listening, and speaking skill contrasts with reading, and writing skill; most of the students classified their listening, and speaking as weak. Among respondents, only few students admitted that their speaking ability is very good, and none of students claimed that their listening skill is very good. In EFL context, speaking and listening are classified as crucial skill in learning process. This finding confirmed the result of a research conducted by Ulum (2015) who stated that listening is the ignored skill in EFL context. Furthermore, this finding supported a claim stated that listening and speaking skill are strongly related (Parnawati and Ulinuha, 2019). Therefore, the teaching method and strategy need to be adjusted to tackle the problem faced, so that the goal is achieved.

Regarding to the topics desired by students and teaching staff of Physical Education study program, most of respondents chose topics that support their future occupation. This affirmed that EFL students realized that the importance of English skill for their future career (Parnawati and Ulinuha, 2019). The students picked topics of English which they believe to be crucial if they want to work in the international level as an athlete, coach, referee, and sport journalist. The selection of these topics of ESP for Physical Education students strengthen the claim that topics in ESP should be specially design to meet the core competencies of the students (Kusni, 2013). This claim is also agreed by Milaningrum and Rahmawaty in (2019) that the English lessons available at university level are not accommodating students' prospect as professional in the future.

Finally, many students stated that they want to be sport journalist in the future which require a well writing skill. Students' motivation to learn writing better supported the claim that most EFL students believe the importance of writing skill for their future career, therefore they want to master this skill (Diana \& Mansur, 2018).

\section{CONCLUSION AND SUGGESTION}

\section{Conclusion}

Based on the findings above, the conclusion that can be derived is that most Physical Education students in Universities in Lampung considered that their English skill is weak. Among those core competencies of English, students are more confident with their reading comprehension 
and writing skill than their listening and speaking ability. In this research, it found that most students want to writing skill more than other skills because of their dreamed occupation as sport journalist. Interestingly, though they are motivated to learn more about writing, but they consider that their grammar skill is bad. Therefore, they also need to learn grammar comprehensively. Furthermore, students also believe that English skill to support their occupation in the future. They believe that English skill will accelerate their career as athlete, coach, and referee in the international level.

\section{Suggestion}

The results and discussion of thus research discussed the aspects that is necessary to be adjusted regarding to context of teaching English for Specific Purposes for Physical Education Students at University setting. The advantages of this research are not only beneficial to the lecturer/practitioner but also for further researchers.

1. For Lecturers/ practitioner, understanding students' language proficiency is crucial in designing teaching materials. Students' weaknesses should be addressed and their strengths should be upgraded.

2. Teaching ESP means preparing student for future context of their career. Therefore, the topic selected should meet the job-related matters and activities as athlete, coach/teacher, referee, and sport journalist.

3. The results of this study are expected to be an assistance for the advancement of ESP syllabus and lessons for Physical Education students.

For the future researcher/teacher/practitioner, this research can be taken as significant reference to accelerate the progress of ESP for Physical Education Students and to perfect syllabus and materials of English for Sports for students at university level. 


\section{ACKNOWLEDGEMENT}

This research is fully funded by the Ministry of Research, Technology and Higher Education of Indonesia.

\section{BIO-PROFILE:}

Budi Eko Pranoto is a Lecturer on Linguistics in Universitas Teknokrat Indonesia. His interest on language study began when he arranged his undergraduate thesis. He then continued his master on Linguistics at Faculty of Humanities, Universitas Indonesia and graduated in 2016. $\mathrm{He}$ is greatly interested in discourse studies (especially politics discourse), corpus linguistic, and language death/ development.

Suprayogi is a lecturer in English Literature Study Program of Universitas Teknokrat Indonesia. He teaches speaking as well as linguistics subject. He obtained his master in Linguistics of Universitas Indonesia. His research interest ranges from English for Specific Purposes to ethnolinguistics and critical discourse analysis. 


\section{REFERENCES}

Akyel, A. S., \& Ozek, Y. (2010). A language needs analysis research at an English medium university in Turkey. Procedia - Social and Behavioral Sciences, 2(2), 969-975. https://doi.org/10.1016/j.sbspro.2010.03.136

Basturkmen, H. (2010). Developing Courses in English for Specific Purposes. Palgrave Macmillan.

Benesch, S. (2001). Critical English for Academic Purposes: Theory, Politics, and Practice. Lawrence Erlbaum Associates.

Boroujeni, S. A., \& Fard, F. M. (2013). A Needs Analysis of English for Specific Purposes (ESP) Course For Adoption Of Communicative Language Teaching :( A Case of Iranian First-Year Students of Educational Administration). International Journal of Humanities and Social Science Invention ISSN, 2(6), 35-44. www.ijhssi.org

Brown, M., \& Hale, K. (2014). Applied Research Methods in Public \& Nonprofit Organization. San Fransisco: Jossey-Bass.

Cohen, L. (2007). Research Methods in Education. In Research Methods in Education. https://doi.org/10.4324/9780203029053

Diana, S., \& Mansur, M. (2018). Need Analysis on English Teaching Materials for Ict Students. ETERNAL (English, Teaching, Learning, and Research Journal), 4(2), 209. https://doi.org/10.24252/eternal.v42.2018.a6

Dudley-Evans,T., \& St. John,M. J. (1998). Developments in English for Specific Purposes: A multi-disciplinary Approach. Cambridge, Cambridge University Press.

Hutchinson, Tom and Waters, A. (1991). English for Specific Purposes. In English for Specific Purposes: A Learning-centered Approach. University of Cambridge. https://doi.org/10.4324/9781315716893-5

Kusni. (2013). Reformulating English for Specific Purposes (ESP) in Indonesia: Current Issues and Future Prospects. SELT 2013 PROCEEDING, 84, 487-492. http://ir.obihiro.ac.jp/dspace/handle/10322/3933

Lee, C.-L. (2016). Principles and Practices of ESP Course Design-A Case Study of. International Journal of Learning, Teaching and Educational Research, 15(2), 94-105.

Li, J. (2014). Needs Analysis of Business English Undergraduates and the Implications to Business English Curriculum Design. Advances in Language and Literary Studies, 5(4). https://doi.org/10.7575/aiac.alls.v.5n.4p.33

Milaningrum, E., \& Rahmawaty, P. (2019). Developing English Module for Hospitality Students Using Inquiry-Based Language Learning in Balikpapan State Polytechnic. Premise: Journal of English Education, 8(1), 1. https://doi.org/10.24127/pj.v8i1.1928

Paltridge, B., \& Starfield, S. (Ed). (2012). English for Research Publication Purposes. In The Handbook of English for Specific Purposes. Wiley-Blackwell. 
https://doi.org/10.1002/9781118339855.ch16

Parnawati, T., \& Ulinuha, A. (2019). English at Higher Education Level: A need Analysis. Premise: Journal of English Education and Applied Linguistics, 8(2), 214-225.

Poedjiastutie, D., \& Oliver, R. (2017). English Learning Needs of Esp Learners: Exploring Stakeholder Perceptions At an Indonesian University. TEFLIN Journal, 28(1), 1-21. https://doi.org/10.15639/teflinjournal.v28i1/1-21

Rokhyati, U. (2013). Teaching English at Higher Education in Indonesia: Searching for Usefulness. SELT, 85(1), 235-240. https://doi.org/10.1016/j.bbapap.2013.06.007

Susandi, N. K., \& Krishnawati, N. L. P. (2016). Needs Analysis : Esp Syllabus Design for Indonesian Efl. The Fourth International Seminar on English Language and Teaching (ISELT-4), 130-140. http://ejournal.unp.ac.id/index.php/selt/issue/view/753

Tomlinson, B. (ed.). (2011). Materials Development in Language Teaching (2nd ed.). Cambridge: Cambridge University Press.

Ulum, Ö. G. (2015). Listening: The Ignored Skill in EFL Context. International Journal of Humanities Social Sciences and Education (IJHSSE), 2(5), 72-76. 